\title{
Somatic and F-specific bacteriophages in waters of the small, municipal Rusałka Lake in Szczecin
}

\author{
MAŁGORZATA PAWLIKOWSKA-WARYCH, ${ }^{1}$ PAULINA CZUPRYŃSKA, ${ }^{2}$ \\ BEATA TOKARZ-DEPTUŁA, ${ }^{3}$ WIESŁAW DEPTUŁA ${ }^{4}$ \\ ${ }^{1}$ Department of Microbiology, Faculty of Biology, University of Szczecin, Felczaka 3c, 71-412 Szczecin, Poland
2 Department of Microbiology, Faculty of Biology, University of Szczecin, Felczaka 3c, 71-412 Szczecin, Poland
${ }_{3}^{3}$ Department of Immunology, Faculty of Biology, University of Szczecin, Felczaka 3c, 71-412 Szczecin, Poland
${ }^{4}$ Nicolaus Copernicus University in Toruń, Faculty of Biological and Veterinary Sciences, Institute of Veterinary Medicine, Gagarina 7,
87-100 Toruń, Poland
}

Corresponding author, e-mail: beata.tokarz-deptula@usz.edu.pl

Keywords Bacteriophages, aqueous environment, environment protect

Abstract Investigations of bacteriophages showed that in the environment are mostly in water, but in small municipal lakes sporadically been studied. Previous studies of bacteriophages in the aqueous environment related to the determination of the quantity and diversity and use them as indicators of water pollution. In the last study probably of the most important are the F-specific and somatic bacteriophages specific to E. coli. In our study examined them in a small municipal lake in Szczecin (Poland) in context of occurrence of F-specific and somatic bacteriophages specific to $E$. coli with used of SAL method. We proved that count of bacteriophages in this water tank is lower in context of different waters, but the relation between the amounts of this viruses and environments condition (air and water temperature) were similar to results observed in waters of seas, rivers and lakes.

Somatyczne i F-specyficzne bakteriofagi małego miejskiego jeziora Rusałka w Szczecinie

Słowa kluczowe bakteriofagi, środowisko wodne, ochrona środowiska

Streszczenie Badania bakteriofagów wykazały, że w środowisku naturalnym znajdują się one głównie w wodzie, ale w małych jeziorach miejskich badano je sporadycznie. Poprzednie badania bakteriofagów w środowisku wodnym dotyczyły określania ilości i różnorodności oraz wykorzystywania ich jako wskaźników zanieczyszczenia wody. Wcześniejsze badania wykazały, że prawdopodobnie najważniejszymi są F-specyficzne i somatyczne bakteriofagi E. coli. W obecnym badaniu oznaczaliśmy je w małym jeziorze miejskim w Szczecinie (Polska), za pomocą metody SAL. Udowodniliśmy, że liczba bakteriofagów w tym zbiorniku jest mniejsza w porównaniu do innych wód, ale związek między liczbą tych wirusów a warunkami środowiska (temperatura powietrza i wody) był podobny do wyników obserwowanych w wodach mórz, rzek i jezior. 


\section{Introduction}

Nonillion $\left(10^{\wedge 30}\right)$ viruses are estimated to exist in the world (Paez-Espino et al., 2016), most of which are bacteriophages occurring in aqueous environment (Breitbart, Rohwer, 2005; PaezEspino et al., 2016). Research into bacteriophages in aqueous environments was conducted on flowing (Brazina, Baldini, 2008; Burbano-Rosero et al., 2011; Cole, Long, Sobsey, 2003; Dore, Henshillwood, Lees, 2000; Duran et al., 2002; Fauvel, Gantzer, Cauchie, Ogorzaly, 2016; Havelaar, van Olphen, Drost, 1993; Hernroth, Conden-Hansson, Rehnstam-Holm, Girones, Allard, 2002; Hot, Legeay, Jacques, Gantzer, Caudrelier, Guyard, 2003; Jiang, Paul, 1994; Jiang, Noble, Chu, 2001; Jiang, Chu, He, 2007; Long, Sobsey, 2004; Moce-Livina, Lucena, Jofre, 2005; Ogorzaly, Tissier, Bertrand, Maul, Ganzer, 2009; Shirasaki, Matsushita, Matsui, Urasaki, Ohno, 2009; Simkova, Cervenka, 1981; Sinton, Finlay R. K., Lynch, 1999; Skraber, Gassilloud, Gantzer, 2004; Stewart et al., 2006; Stewart-Pullaro et al., 2006; Zupok, Sokołowska, Śliwa-Dominiak, Tokarz-Deptuła, 2010) and standing waters, but mainly on large lakes (Demuth, Neve, Witzel, 1993; Drucker, Dutova, 2006; Dryden, Ramaswami, Yuan, Giammar, Angenet, 2006; Havelaar et al., 1993; Hennes, Simon, 1995; Jiang, Paul, 1994; Pusch et al., 2005; Stewart, Vinje, Oudejans, Scott, Sobsey, 2006; Stewart-Pullaro et al., 2006; Śliwa-Dominiak, Tokarz-Deptuła, Deptuła, 2010, 2014; Zupok et al., 2010), the water of seas and oceans (Dore et al., 2000; Hernroth et al., 2002; Jiang, Paul, 1994; Jiang et al., 2007; Moce-Livina et al., 2005; Rava, Sarreal, 2016; Sinton et al., 1999; Stewart et al., 2006; Suttle, 2007) and drinking water (Pelleieux, Mathieu, Block, Gantzer, Bertramd, 2016; Vergara, Goh, Rezaeinejad, Sobsey, Gin, 2015). Despite an essential role municipal lakes play relative to their location in a city and their recreational character, there exists little body of literature on phages found in the water of small lakes, including municipal lakes. Those papers focused on somatic bacteriophages (Brazina, Baldini, 2008; Burbano-Rosero et al., 2011; Demuth et al., 1993; Dore et al., 2000; Hennes, Simon, 1995; Hot et al., 2003; Jiang, Paul, 1994; Moce-Livina et al., 2005; Pusch et al., 2005; Sinton et al., 1999; Skraber et al., 2004; Śliwa-Dominiak et al., 2014; Zupok et al., 2010), F-RNA (Cole et al., 2003; Demuth et al., 1993; Dore et al., 2000; Dryden et al., 2006; Duran et al., 2002; Fauvel et al., 2016; Havelaar et al., 1993; Hennes, Simon, 1995; Hernroth et al., 2002; Jiang, Paul, 1994; Jiang et al., 2001; Jiang et al., 2007; Long, Sobsey, 2004; Moce-Livina et al., 2005; Ogorzaly, Tissier, Bertrand, Maul, Ganzer,. 2009; Olson, Axler, Hicks, Henneck, McCarthy, 2005; Pusch et al., 2005; Shirasaki et al., 2009; Simkova, Cervenka, 1981; Sinton et al., 1999; Stewart et. al., 2006; Stewart-Pullaro et al., 2006; Śliwa-Dominiak et al., 2010, 2014; Vergara et al., 2015; Zupok et al., 2010) and F-DNA phages (Cole et al., 2003; Hennes, Simon, 1995; Jiang, Paul, 1994; Jiang et al., 2001; Long, Sobsey, 2004; Pusch et al., 2005; Zupok et al., 2010) and on Bacterioides fragilis bacteriophages (MoceLivina et al., 2005; Ogorzaly et al., 2009; Skraber et al., 2004). Bacteriophages were identified in observational studies and when aqueous environments were evaluated for water pollution, phages were detected together with E. coli bacteria (Brazina, Baldini, 2008; Burbano-Rosero et al., 2011; Dore et al., 2000; Fauvel et al., 2016; Hernroth et al., 2002; Jiang, Paul, 1994; Jiang et al., 2001; Moce-Livina et al., 2005; Ogorzaly et al., 2009; Olson et al., 2005; Pusch et al., 2005; Sinton et al., 1999; Skraber et al., 2004; Śliwa-Dominiak et al., 2010, 2014; Vergara et al., 2015) and Enterococcus faecalis (Havelaar et al., 1993; Jiang, Paul, 1994; Jiang et al., 2001; Moce-Livina et.al., 2005; Ogorzaly et al., 2009; Pusch et al., 2005; Sinton et al., 1999; Skraber et al., 2004). In the latter, F-specific genogroups of RNA bacteriophages were characterized (Cole et al., 2003; Demuth et al., 1993; Dore et al., 2000; Dryden et al., 2006; Duran et al., 2002; Fauvel et al., 2016; Havelaar et al., 1993; Hennes, Simon, 1995; Hernroth et al., 2002; Hot et al., 2003; Jiang, 
Paul, 1994; Jiang et al., 2001; Jiang et al., 2007; Long, Sobsey, 2004; Moce-Livina et al., 2005; Ogorzaly et al., 2009; Pusch et al., 2005; Shirasaki et al., 2009; Simkova, Cervenka, 1981; Sinton et al., 1999; Stewart et al., 2006; Stewart-Pullaro et al., 2006; Śliwa-Dominiak et al., 2010, 2014; Zupok et al., 2010), as genogroups I and IV are common in zoonotic while genogroups II and III in human contamination (Cole et al., 2003; Fauvel et al., 2016; Long, Sobsey, 2004; MoceLivina et al., 2005; Stewart et al., 2006; Stewart-Pullaro et al., 2006; Śliwa-Dominiak et al., 2014; Vergara et al., 2015). Observational studies were carried out on the effect of the number of somatic bacteriophages (Jiang, Paul, 1994; Moce-Livina et al., 2005) and F-specific RNA bacteriophages on the number of people-infecting viruses (Hernroth et al., 2002; Jiang, Paul, 1994; Jiang et al., 2001; Moce-Livina et al., 2005; Ogorzaly et al., 2009; Vergara et al., 2015). Research was done on the effect of somatic bacteriophages (Hot et al., 2003; Pusch et al., 2005; Simkova, Cervenka, 1981; Skraber et al., 2004) and F-specific RNA bacteriophages (Havelaar et al., 1993; Jiang et al., 2001; Ogorzaly et al., 2009; Pusch et al., 2005; Simkova, Cervenka, 1981; Vergara et al., 2015) on the number of viruses infecting animals. Bacteriophages in aqueous environments (Hennes, Simon, 1995; Jiang et al., 2007; Śliwa-Dominiak, Tokarz-Deptuła, Deptuła, 2015) were determined as part of the microbial loop. By killing bacteria, they promote the release of compounds of carbon, nitrogen and phosphorus into the environment, all of which are important building blocks of life, and particularly in case of plankton. Some studies focused on the impact of temperature in the environment (Cole et al., 2003; Dore et al., 2000; Fauvel et al., 2016; Hernroth et al., 2002; Jiang, Paul, 1994; Long, Sobsey, 2004; Olson et al., 2005; Ravva, Sarreal, 2016; Simkova, Cervenka, 1981; Sinton et al., 1999; Skraber et al., 2004; Śliwa-Dominiak et al., 2010, 2014), including exposure to sunlight (Cole et al., 2003; Dore et al., 2000; Fauvel et al., 2016; Hernroth et al., 2002; Sinton et al., 1999; Śliwa-Dominiak et al., 2015) on the water levels of somatic bacteriophages (Duran et al., 2002; Hernroth et al., 2002; Jiang, Paul, 1994; Simkova, Cervenka, 1981; Sinton et al., 1999; Skraber et al., 2004) and F-specific RNA bacteriophages (Cole et al., 2003; Dore et al., 2000; Fauvel et al., 2016; Hernroth et al., 2002; Jiang, Paul, 1994; Long, Sobsey, 2004; Ravva, Sarreal, 2016; Sinton et al., 1999; Śliwa-Dominiak et al., 2010, 2014; Vergara et al., 2015). They regulate $E$. coli levels which determine water clarity.

As there is no data on bacterial viruses in the water of small, municipal lakes other that collected by our team on FRNA phages (Śliwa-Dominiak et al., 2010, 2014; Zupok et al., 2010), we identified somatic and F-specific RNA and DNA bacteriophages in the water of a municipal Lake Rusałka in Szczecin, within the framework of four seasons (spring, summer, autumn, winter), understood to be an element conditioning the effect of water and air temperature on the amount of examined bacteriophages.

\section{Experimental procedures}

Rusałka Lake, with its area of 3.7 hectares, is located in the centre of Szczecin. It is elongated in shape, $670 \mathrm{~m}$ long and approximately $40 \mathrm{~m}$ wide (at its widest point). It is a shallow reservoir of the max depth of $2 \mathrm{~m}$ and it is substantially silted. It is a flow-through reservoir as it is fed by the water of Osówka stream and surplus water can escape through an underwater pipeline running through Niecka Niebuszewska and Stocznia Szczecińska (Szczecin Shipyard) into the West Oder (Hłynczak, Deptuła, Możdżer, Poleszczuk, Słupińska, 1995). Water samples were taken once at two points: at the inlet of the stream (point A) and at the opposite direction, at its outlet (point B). The distance between points A and B was approximately $670 \mathrm{~m}$. Samples were taken in four seasons; spring, summer, autumn and winter. Water sampling, water and air temperature 
measurement procedures complied with PN-EN ISO 19458 standards (19 December 2007, Polish Committee for Standardisation). The amount of somatic and F-specific RNA and DNA bacteriophages identified in water samples taken at points $\mathrm{A}$ and $\mathrm{B}$ in spring, summer, autumn and winter was determined with Single Agar Layer SAL (Annon: Method 1602: Male- specific (F+) and Somatic Coliphage in Water by Single Agar Layer (SAL) Procedure. 2001, EPA, Washington D.C.). In bacteriophages plaque assay, phages were determined as the number of plaque forming units (PFU) in ml of examined water. Different strains of Escherichia (E.) coli were used to detect and determine phages concentration. Nalidixic acid-resistant E. coli CN13 was used for somatic bacteriophages while ampicillin and streptomycin-resistant E. coli Famp strain was used for F-specific RNA and DNA bacteriophages.

To obtain clean cultures, commercial strains of E. coli CN13 and E. coli Famp were in line with the requirements grown on Tryptic Soy Agar - TSA solid medium, inoculated with an antibiotic. Each colony was then transferred to TSB liquid medium and each was grown in the presence of antibiotics it was resistant to. To identify somatic bacteriophages and F-specific RNA and DNA phages, medium consisted of $100 \mathrm{ml}$ of water taken in the sampling points, $100 \mathrm{ml}$ of double concentrated TSA (Triptic Soya Agar), $0.5 \mathrm{ml}$ of sterile solution of $\mathrm{MgCl} 2 \times 6 \mathrm{H} 2 \mathrm{O}$ with a concentration of $0.0814 \mathrm{~g} / \mathrm{ml}, 2 \mathrm{ml}$ of antibiotic (Nalidixic acid for E. coli CN13 and a mixture of ampicillin and streptomycin for E. coli Famp) and $10 \mathrm{ml}$ of 24-hour broth culture (E. coli CN13 or E. coli Famp).

All constituent elements were mixed and transferred to Petri dishes which were incubated for $24 \mathrm{~h}$ at $37^{\circ} \mathrm{C}$ and PFUs were counted. Results from bacteriophage plaque assay of somatic bacteriophages and F-specific RNA and DNA phages in the samples of water taken in points A and $\mathrm{B}$, considering their dependence on temperature of water and air and resulting from seasonal changes were used for statistical analysis (Kończak, Trzpiot 2002). Sperman's rank correlation coefficient was calculated. It determines dependence (correlation) between examined variables and it has a value in the interval $(-1,1)$. The method (Ostasiewicz, Rusnak, Siedlecka, 2003), which is used for correlation power determination, assumes that if its value is in the range of $0-0.2$, it means weak correlation, $0.2-0.4$ low correlation, $0.4-0.7$ moderate correlation, $0.7-0.9$ significant correlation and over 0.9 very strong correlation.

\section{Results}

Analysis of somatic bacteriophages and F-specific RNA and DNA phages in the samples of water taken in points $\mathrm{A}$ in spring, summer, autumn and winter showed the levels of somatic bacteriophages in spring, in water temperature of $7^{\circ} \mathrm{C}$ and air temperature of $9^{\circ} \mathrm{C}$ was $0,3 \mathrm{PFU}$

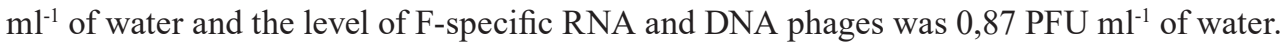

In summer, at $13^{\circ} \mathrm{C}$ in water and $20^{\circ} \mathrm{C}$ in the air, results were $6,06 \mathrm{PFU} \mathrm{ml}^{-1}$ of water for somatic bacteriophages and 23,87 for F-specific RNA and DNA phages. In autumn, at $12^{\circ} \mathrm{C}$ in water and $8.5^{\circ} \mathrm{C}$ in the air, results were 21,08 for somatic bacteriophages and $0,65 \mathrm{PFU} \mathrm{ml}^{-1}$ of water for F-specific RNA and DNA phages. In winter, at $3^{\circ} \mathrm{C}$ in water and $-3^{\circ} \mathrm{C}$ in the air, results were 20,85 PFU ml-1 of water for somatic bacteriophages and 1,17 $\mathrm{PFU} \mathrm{ml}^{-1}$ of water for F-specific RNA and DNA phages (Table 1). 
Table 1. The count of somatic and F-specific DNA and RNA bacteriophages in water samples from Rusałka lake and temperatures of water and air in point $\mathrm{A}$ and $\mathrm{B}$

\begin{tabular}{|c|c|c|c|c|c|c|c|c|}
\hline \multirow[t]{2}{*}{ Season of water samples taken } & \multicolumn{2}{|c|}{$\begin{array}{l}\text { Count of somatic } \\
\text { bacteriophages } \\
(\text { PFU ml }\end{array}$} & \multicolumn{2}{|c|}{$\begin{array}{l}\text { Count of F-specific } \\
\text { bacteriophages } \\
\left(\mathrm{PFU} \mathrm{m} \mathrm{ml}^{-1}\right)\end{array}$} & \multicolumn{2}{|c|}{$\begin{array}{l}\text { Temperature } \\
\text { of water } \\
\left({ }^{\circ} \mathrm{C}\right)\end{array}$} & \multicolumn{2}{|c|}{$\begin{array}{c}\text { Temperature } \\
\text { of air } \\
\left({ }^{\circ} \mathrm{C}\right)\end{array}$} \\
\hline & A & B & A & B & A & B & A & B \\
\hline Spring & 0.300 & 0.130 & 0.870 & 0.000 & 7.0 & 7.6 & 9.0 & 9.0 \\
\hline Summer & 6.060 & 0.170 & 23.870 & 0.000 & 13.0 & 18.0 & 20.0 & 17.0 \\
\hline Autumn & 21.080 & 0.720 & 0.650 & 0.050 & 12.0 & 14.8 & 8.5 & 9.0 \\
\hline Winter & 20.850 & 3.870 & 1.170 & 0.060 & 3.0 & 0.0 & -3.0 & -4.0 \\
\hline $\begin{array}{l}\text { The average count of bacterio- } \\
\text { phages in } 4 \text { seasons of year }\end{array}$ & 12.073 & 1.223 & 6.640 & 0.0275 & 8.8 & 10.1 & 8.6 & 7.8 \\
\hline
\end{tabular}

Explenation: $\mathrm{PFU}$ - plaque forming unit; $\mathrm{A}, \mathrm{B}$ - water points.

In summary, the maximum and minimum levels of somatic bacteriophages were in autumn and winter and in spring, respectively at point $\mathrm{A}$ in four seasons. The maximum and minimum levels of F-specific RNA and DNA phages were in summer and autumn, respectively. However, the average count of somatic bacteriophages, in four seasons, at point A relative to F-specific RNA and DNA phages was higher twice, 12,073 PFU ml-1 of water for somatic bacteriophages. The average count of F-specific RNA and DNA phages was 6,64, for average water and air temperature for four seasons of $8.8^{\circ} \mathrm{C}$ and $8.6^{\circ} \mathrm{C}$, respectively.

A similar phages analysis at point $\mathrm{B}$ showed $0,13 \mathrm{PFU} \mathrm{ml}^{-1}$ for somatic bacteriophages, at water temperature of $7.6^{\circ} \mathrm{C}$ and air temperature $9.0^{\circ} \mathrm{C}$. No F-specific RNA and DNA phages were found. In summer, at water temperature of $18^{\circ} \mathrm{C}$ and air temperature of $17^{\circ} \mathrm{C}$, the number of somatic bacteriophages was 0,17 PFU ml-1. Just like in spring, no F-specific RNA and DNA phages were found. In autumn, at water temperature of $14.8^{\circ} \mathrm{C}$ and air temperature of $9^{\circ} \mathrm{C}$, the number

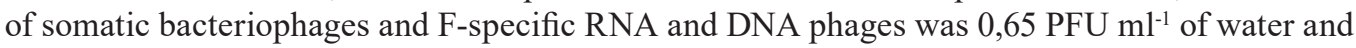
$0,05 \mathrm{PFU} \mathrm{ml} l^{-1}$, respectively. In winter, at water temperature of $0^{\circ} \mathrm{C}$ and air temperature of $-4^{\circ} \mathrm{C}$, the number of somatic bacteriophages and F-specific RNA and DNA phages was 3,87 PFU ml-1 of water and 0,06 PFU ml-1 , respectively.

To sum up results of samples taken at point B of the investigated lake, in four seasons, the maximum and minimum levels of somatic bacteriophages were in winter and in spring, respectively. The maximum levels of F-specific RNA and DNA phages were in autumn and winter, and in spring and summer there was no bacteriophages.

However, the average count of somatic bacteriophages, in four seasons, at point B relative to F-specific RNA and DNA phages was 60 times higher, 1.223 $\mathrm{PFU} \mathrm{ml}^{-1}$ for somatic bacteriophages. The average count of F-specific RNA and DNA phages was 0.0275 , for average water and air temperature for four seasons of $10.1^{\circ} \mathrm{C}$ and $7.8^{\circ} \mathrm{C}$, respectively.

To evaluate the number of phages at points $\mathrm{A}$ and $\mathrm{B}$, in four seasons, the maximum levels of somatic bacteriophages and F-specific RNA and DNA phages were found at point A: in autumn and winter for the former and in summer for the latter. The minimum levels of somatic bacteriophages and F-specific RNA and DNA phages were found at point A: in spring for the former and in spring and summer for the latter. To evaluate the averaged number of the phages, for four seasons, at points $\mathrm{A}$ and $\mathrm{B}$ where samples were taken, the number of somatic bacteriophages at point A was 10 times higher compared to point B and that of F-specific RNA and DNA phages 
was over 200 times higher at point A compared to point B. Water average temperature, for four seasons, at point A compared to point $\mathrm{B}$ was $1.3^{\circ} \mathrm{C}$ lower and that of air was $0.8^{\circ} \mathrm{C}$ higher.

Correlation between somatic bacteriophages number and water and air temperature at point A was negative (Table 2).

Table 2: Sperman's rank correlation coefficient (a) and correlation power (b) between count of somatic or F-specific (DNA and RNA) bacteriophages and temperatures of water and air in point A and B.

\begin{tabular}{|c|c|c|c|c|}
\hline & \multicolumn{2}{|c|}{ Point A } & \multicolumn{2}{|c|}{ Point B } \\
\hline & $\begin{array}{l}\text { count of somatic } \\
\text { bacteriophages } \\
\left(\text { PFU ml }{ }^{-1}\right)\end{array}$ & $\begin{array}{c}\text { count of F-specific } \\
\text { bacteriophages } \\
\left(\mathrm{PFU} \mathrm{ml} \mathrm{H}^{-1}\right)\end{array}$ & $\begin{array}{c}\text { count of somatic } \\
\text { bacteriophages } \\
(\text { PFU ml- })\end{array}$ & $\begin{array}{c}\text { count of F-specific } \\
\text { bacteriophages } \\
\left(\mathrm{PFU} \mathrm{ml} \mathrm{m}^{-1}\right)\end{array}$ \\
\hline $\begin{array}{l}\text { Temperature } \\
\text { of water }\left({ }^{\circ} \mathrm{C}\right)\end{array}$ & $\begin{array}{l}\text { a) }-0.17809 ; \\
\text { b) weak correlation }\end{array}$ & $\begin{array}{l}\text { a) } 0.59524 ; \\
\text { b) moderate } \\
\text { correlation }\end{array}$ & $\begin{array}{l}\text { a) }-0.80786 \text {; } \\
\text { b) } \begin{array}{l}\text { significant } \\
\text { correlation }\end{array}\end{array}$ & $\begin{array}{l}\text { a) }-0.48188 ; \\
\text { b) moderate } \\
\text { correlation }\end{array}$ \\
\hline $\begin{array}{l}\text { Temperature } \\
\text { of air }\left({ }^{\circ} \mathrm{C}\right)\end{array}$ & 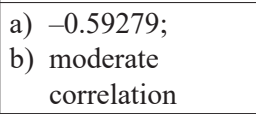 & $\begin{array}{l}\text { a) } 0.79745 ; \\
\text { b) } \begin{array}{l}\text { significant } \\
\text { correlation }\end{array}\end{array}$ & $\begin{array}{l}\text { a) }-0.91992 ; \\
\text { b) very strong } \\
\text { correlation }\end{array}$ & $\begin{array}{l}\text { a) }-0.76944 \text {; } \\
\text { b) significant } \\
\text { correlation }\end{array}$ \\
\hline
\end{tabular}

Explenation: $\mathrm{PFU}$ - plaque forming unit; $\mathrm{A}, \mathrm{B}$ - water point.

Its correlation power being an absolute value of correlation coefficient of 0.17809 suggests weak correlation. However, although correlation between bacteriophage number and air temperature at point A was negative, its correlation coefficient of -0.59279 suggest moderate correlation.

Correlation between F-specific RNA and DNA phage number and water temperature at point A was positive, with correlation coefficient of 0.59524 which suggest moderate correlation. Correlation between F-specific RNA and DNA phage number and air temperature at point A was positive, with correlation coefficient of 0.79745 which suggests significant correlation.

A similar evaluation of correlation at point B between somatic becteriophage number and water temperature was negative, with a power of -0.80786 which suggests significant correlation. Correlation between the number of somatic bacteriophages and air temperature at the same point was negative, with a power of -0.91992 which suggests very strong correlation. Correlation between F-specific RNA and DNA phage number and water temperature was negative, with correlation coefficient of -0.48188 which suggests moderate correlation. Correlation between F-specific RNA and DNA phage number and air temperature was negative, with correlation coefficient of -0.76944 which suggests significant correlation.

To sum up results of correlation between phage number and water and air temperature at points $\mathrm{A}$ and $\mathrm{B}$, weak correlation was found only between somatic bacteriophage number and water temperature at point A. Moderate correlation was found between F-specific RNA and DNA phage number and water temperature and between somatic bacteriophage number and air temperature at point $\mathrm{A}$ and between F-specific RNA and DNA phage number and water temperature at point $\mathrm{B}$.

Significant correlation was found between F-specific RNA and DNA phage number and air temperature at point $\mathrm{A}$ and between somatic bacteriophage number and water temperature and between F-specific RNA and DNA phage number and air temperature at point B. Strong correlation was found between somatic bacteriophage number and air temperature at point $\mathrm{B}$. 


\section{Discussion of results}

Interpretation of data about somatic bacteriophage number and F-specific RNA and DNA phage number in the water of a small lake in Szczecin is difficult as there is no relative research conducted on similar water reservoirs other than our own studies on the number of F-RNA phages in water samples from two small lakes in Szczecin - Rusałka (Śliwa-Dominiak et al., 2010, 2014) and Syrenie Stawy (Zupok et al., 2010). However, the number of investigated F-RNA bacteriophages of 23,00 was substantially lower than that found in large water reservoirs and very large lakes of Constans (Germany), between 5,000 and 25,000 bacteriophage particles (Henne, Simon, 1995), Plußsee (Germany), over 40 phages (Demuth et al., 1993), and Baikal (Russia), becteriophage number of $10^{8}$ per $\mathrm{ml}$ of water (Drucker, Dutova, 2006).

Based on our own data, the maximum number of somatic bacteriophages were at point $\mathrm{A}$, in autumn and winter and the minimum number at point $\mathrm{B}$, in spring. This is confirmed in phage levels relative to their averaged number in four seasons as phage number at point $\mathrm{A}$ was 10 times higher than that at point B. This is probably because at point A, the stream inlet, there are more bacteria, meaning food for phages. Our results showing higer levels of somatic bacteriophages in autumn and winter relative to spring and summer are consistent with those of Plu $\beta$ see (Germany) (Demuth et al., 1993) and Baikal (Russia) (Drucker, Dutova, 2006) where decreasing environment temperature resulted in higher phage levels. This seems to be related to the fact that in warmer months, relative to colder months, water is more exposed to UV radiation and its more intensive impact and finally to destruction of bacterial viruses (Demuth et al., 1993).

The maximum number of F-specific RNA and DNA phages at point A was in summer and the minimum number at point $\mathrm{B}$ was in summer and spring which is consistent, similarly to somatic bacteriophages, with their number averaged for four seasons as their number was 200 times higher at point A relative to point $\mathrm{B}$. That data, similarly to somatic bacteriophage data, can be related to higher levels of bacteria in water, at point A, the stream inlet to the lake. To sum up, data on F-specific RNA and DNA phage number relative to season are not fully consistent with earlier data from a study on F-RNA phages (Śliwa-Dominiak et al., 2010, 2014; Zupok et al., 2010) conducted in in the water of a similar watershed. The earlier data demonstrated higher phage levels in winter months compared to summer and our data showed their maximum levels in summer and minimum levels in autumn. This might be due to the fact that while in the recent study F-RNA and DNA phages were examines, only F-RNA phages were analysed in the earlier study.

Higher levels of somatic and F-specific RNA and DNA phage numbers at point A, compared to point $\mathrm{B}$, are probably due to higher numbers of microorganisms, including E. coli, in the stream at point $\mathrm{A}$ and due to lower temperature of water at point $\mathrm{A}$, compared to point $\mathrm{B}$. The latter correlation was confirmed in many other studies (Cole et al., 2003; Dore et al., 2000; Fauvel et al., 2016; Hernroth et al., 2002; Jiang, Paul, 1994; Long, Sobsey, 2004; Ravva, Sarreal, 2016; Simkova, Cervenka, 1981; Sinton et al., 1999; Skraber et al., 2004; Śliwa-Dominiak et al., 2010, 2014) in which also water temperature was demonstrated to be conducive to phage proliferation, in line with a rule of virusology that says that viruses are not very susceptible to low temperatures.

However, the fact that the number of somatic phages was twice as high as that of F-specific phages confirms data from a study on the Mediterrianian Sea close to Barcelona (Moce-Livina et al., 2005), Werbeline Lake in central Germany (Pusch et al., 2005) and drinking water watershed in Singapore (Vergara et al., 2015) where also more somatic than F-specific phages were found. It is thought to be linked to the fact that somatic phages are more resistant to external factors, including exposure to sunlight, environment temperature and presence of organic matter 
(Hernroth et al., 2002; Jiang, Paul, 1994; Sinton et al., 1999). This was also confirmed in a study on the effect of temperature and salinity on bacteriophages from the estuary of a river in California (Havelaar et al., 1993), an observational study on the effect of organic matter in wastewater in Sydney (Australia) (Olson et al., 2005), a study on the effect of water temperature and chlorophyll concentration in Constance Lake (Germany) (Hennes, Simon, 1995) which demonstrated that F-specific phages were more susceptible to these factors than somatic phages. Those earlier findings regarding higher resistance of somatic phages, compared to F-specific RNA and DNA phages, to environmental conditions confirm our own data on correlation between somatic and F-specific RNA and DNA phage numbers and temperature of water and air.

Stronger correlation was demonstrated between environmental conditions (air and water) and F-specific RNA and DNA phage numbers than that between environmental conditions and somatic phages. This observation was confirmed in other research studies (Cole et al., 2003; Dore et al., 2000; Fauvel et al., 2016; Hernroth et al., 2002; Jiang, Paul, 1994; Long, Sobsey, 2004; Olson et al., 2005; Simkova, Cervenka, 1981; Sinton et al., 1999; Skraber et al., 2004; Stewart et al., 2006; Śliwa-Dominiak et al., 2010, 2014) which showed that water temperature affects phage levels to a larger degree, although it depends itself on air temperature. The same picture was presented in research on different watersheds, including large lakes located outside city centres, e.g. Table Rock Lake (USA) (Dryden et al., 2006), Baikal Lake (Russia) (Drucker, Dutova, 2006), Plußsee Lake (Germany) (Demuth et al., 1993), North Sea water (England) (Dore et al., 2000), estuaries of a river in California (USA) (Jiang, Paul, 1994), Norwegian fiords (Hernroth et al., 2002), Tampa Bay in Florida (USA) (Jiang et al., 2007) and water from Alzette River in Luxemburg (Fauvel et al., 2016), where high correlation between F-specific RNA phages, water temperature and their maximum level was recorded in colder, winter months. That data confirms our own data on F-RNA phages in the water of small lakes in Szczecin, in which their highest levels were recorded in winter (Śliwa-Dominiak et al. 2010, 2014)

\section{Conclusions}

1. Although the number of somatic and F-specific RNA and DNA phages in water samples from a municipal Rusałka Lake was 3,000 times lower than that of Contans Lake (Germany) (Hennes, Simon, 1995) and 8 times lower than that of Plußsee Lake (Germany) (Demuth et al., 1993), our results show, without doubt, that phage presence also in small water reservoires, similarly to large reservoires, depends on and involves environmental conditions, including temperature of air and water (Cole et al., 2003; Dore et al., 2000; Fauvel et al., 2016; Hernroth et al., 2002; Jiang, Paul, 1994; Long, Sobsey, 2004; Olson et al., 2005; Simkova, Cervenka, 1981; Sinton et al., 1999; Skraber et al., 2004; Stewart et al., 2006; Śliwa-Dominiak et al., 2010, 2014). Our observations also confirm that, similarly to waters of large watersheds, there are more somatic than F-specific RNA and DNA phages, as the former are less susceptible to environmental conditions (Hernroth et al., 2002; Moce-Livina et al., 2005; Pusch et al., 2005; Sinton et al., 1999; Vergara et al., 2015).

2. Bacteriophages assay data, and particularly findings on F-specific RNA and DNA phages in small, municipal lake water, confirm their presence (Śliwa-Dominiak et al., 2010, 2014; Zupok et al., 2010) which seems to prove that water purity evaluation of aquous environments, including small lakes, should consider F-RNA phage presence in this environment, as it may affect the coliform count which determines water clarity. 


\section{References}

Breitbart, M., Rohwer, F. (2005). Here a virus, there a virus, everywhere the same virus? Trends Microbiol., 13, 278-284.

Brezina, S.S., Baldini, M.D. (2008). Detection of somatic coliphages as indicators of fecal contamination in estuarine waters. Rev. Argent. Microbiol., 40, 72-74.

Burbano-Rosero, E.M., Ueda-Ito, M., Kisielius, J.J., Nagasse-Sugahara, T.K., Almeida, B.C., Souza, C.P., Markman, C., Martins, G.G., Albertini, L., Rivera, I.N.G. (2011). Diversity of somatic coliphages in coastal regions with different levels of anthropogenic activity in Sao Paulo State, Brazil. Appl. Environm. Microbiol., 77, 4208-4216.

Cole, D., Long, S.C., Sobsey, M.D. (2003). Evaluation of F+ RNA and DNA coliphages as source-specific indicators of fecal contamination in surface water. Appl. Environm. Microbiol., 69, 6507-6514.

Demuth, J., Neve, H., Witzel, K. (1993). Direct electron microscopy study on morphological diversity of bacteriophage populations in lake Plußsee. Appl. Environm. Microbiol., 59, 3378-3384.

Dore, W., Henshillwood, K., Lees, D. (2000). Evaluation of F- specific RNA bacteriophages as a candidate human enteric virus indicator for bivalve Molluscan Shellfish. Appl. Environm. Microbiol., 66, $1280-1285$.

Drucker, V.V., Dutova, N.V. (2006). Study of the morphological diversity of bacteriophages in Lake Bajkal. Russ. Dok. Akad. Nauk, 410, 421-423.

Dryden, S.K., Ramaswami, B., Yuan, Z., Giammar, D.E., Angenet, L.T. (2006). A rapid reverse transcription-PCR assay for F+RNA coliphges to trace fecal pollution in Table Rock Lake on the ArkansasMissouri border. Water Res., 40, 3719-3724.

Duran, A.E., Muniesa, M., Mendez, X., Valero, F., Lucena, F., Jofre, J. (2002). Removal and inactivation of indicator bacteriophages in fresh waters. J. Appl. Microbiol., 92, 338-347.

Fauvel, B., Gantzer, Ch., Cauchie, H.-M., Ogorzaly, L. (2016). In situ dynamics of F-specific RNA bacteriophages in small river: new way to assess viral propagation in water quality studies. Food Environm. Virol. DOI: 10.1007/s12560-016-9266-0.

Havelaar, A.H., van Olphen, M., Drost, Y.C. (1993). F-specific RNA bacteriophages are adequate model organisms for enteric viruses in fresh water. Appl. Evironm. Microbiol., 59, 2956-2962.

Hennes, K., Simon, M. (1995). Significance of bacteriophages for controlling bacterioplancton growth in a mesotrophic lake. Appl. Environm. Microbiol., 61, 333-340.

Hernroth, B.E., Conden-Hansson, A., Rehnstam-Holm, A., Girones, R., Allard, A.K. (2002). Environmental factors influencing human viral pathogens and their potential indicator organisms in the blue mussel, Mytilus edulis: the first Scandinavian report. Appl. Environm. Microbiol., 68, 4523-4530.

Hłyńczak, A., Deptuła, W,. Możdżer, A., Poleszczuk, G., Słupińska, A. (1995). Ecological importance of water reservoirs in the urban areas on the examples of Rusałka in Szczecin. Aura, 2, 9-11 (in Polish).

Hot, D., Legeay, O., Jacques, J., Gantzer, C., Caudrelier, Y., Guyard, K. (2003). Detection of somatic phages, infectious enteroviruses and enterovirus genomes as indicators of human enteric viral pollution in surface water. Water Res., 37, 4703-4710.

Jiang, S.C., Paul, J.H. (1994). Seasonal and diel abundance of viruses and occurrence of lysogeny/bacteriocinogeny in the marine environment. Marine Ecology Progres Series, 104, 163-172.

Jiang, S., Noble, R., Chu, W. (2001). Human adenoviruses and coliphages in urban runoff-impacted coastal waters of Southern California. Appl. Environm. Microbiol., 67, 179-184.

Jiang, S.C., Chu, W., He, J.-W. (2007). Seasonal detection of human viruses and coliphages in Newport Bay, California. Appl. Environm. Microbiol., 73, 6468-6474. 
Kończak, G., Trzpiot, G. (2002). Statistical analysis of the spreadsheet Microsoft Exel. Economic Academy Press of. Karol Adamiecki. Katowice (in Polish).

Long, S.C., Sobsey, M.D. (2004). A comparison of the survival of F+RNA and F+DNA coliphages in lake water microcosms. J. Water Health, 2, 15-22.

Moce-Llivina, L., Lucena, F., Jofre, J. (2005). Enteroviruses and bacteriophages in bathing waters. Appl. Environm. Microbiol., 71, 6838-6844.

Ogorzaly, L., Tissier, A., Bertrand, I., Maul, A., Ganzer, C. (2009). Relationship between F-specific RNA phage genogroups, faecal pollution indicators and human adenoviruses in river water. Water Res., 43, $1257-1264$.

Olson, M.R., Axler, R.P., Hicks, R.E., Henneck, J.R., McCarthy, B.J. (2005). Seasonal virus removal by alternative onsite wastewater treatment systems. J. Water Health, 3, 139-155.

Ostasiewicz, S., Rusnak, Z., Siedlecka, U. (2003). Statystyka elementy teorii i zadania. Wrocław: Economic Academy of Oskar Lange Press.

Paez-Espino, D., Eloe-Fadrosh, E.A., Pavlopoulos, G.A., Thomas, A.N.D., Huntemann, M., Mikhailova, N., Rubin, E., Ivanova, N.N., Kyrpides, N.C. (2016). Uncovering Earth's virome. Nature, 536, 425-430.

Pelleieux, S., Mathieu, L., Block, J.-C., Gantzer, C., Bertramd, I. (2016). The effect of chlorinationand hydrodynamic shear stress on the persistence of bacteriophages associated with drinking water biofilms. J. Appl. Microbiol., 121, 1189-1197.

Pusch, D., Oh, D.-Y., Wolf, S., Dumke, R., Schroter-Bobsin, U., Hohne, M., Roske, I., Schreier, E. (2005). Detection of enteric viruses and bacterial indicators in German environmental waters. Arch. Virol., 150, 929-947.

Ravva, S.V., Sarreal, Ch.Z. (2016). Persistence of F-specific RNA coliphages in surface waters from a produce production region along the central coast of California. PLOS ONE, 11, e0146623.

Shirasaki, N., Matsushita, T., Matsui, Y., Urasaki, T., Ohno, K. (2009). Comparison of behaviors of two surrogates for pathogenic waterborne viruses, bacteriophages QB and MS2, during the aluminum coagulation process. Water Res., 43, 665-615.

Simkova, A., Cervenka, J. (1981). Coliphages as ecological indicators of enteroviruses in various water systems. Bull. WHO, 59, 611-618.

Sinton, L.W., Finlay, R.K., Lynch, P.A. (1999). Sunlight inactivation of fecal bacteriophages and bacteria in sewage-polluted seawater. Appl. Environm. Microbiol., 65, 3605-3613.

Skraber, S., Gassilloud, B., Gantzer, C. (2004). Comparison of coliforms and coliphages as tools for assessment of viral contamination in river water. Appl. Environm. Microbiol., 70, 3644-3649.

Stewart, J.R., Vinje, J., Oudejans, S.J.G., Scott, G.I., Sobsey, M.D. (2006). Sequence variation among group III F-specific RNA coliphages from water samples and swine lagoon. Appl. Environm. Microbiol., 72, $1226-1230$.

Stewart-Pullaro, J., Daugomah, J.W., Chestnut, D.E., Grave, D.A., Sobsey, M.D., Scott, G.I. (2006). F+RNA coliphage typing for microbial source tracking in surface waters. J. Appl. Microbiol., 101, 1015-1026.

Suttle, C.A. (2007). Marine viruses - major players in the global ecosystem. Nature Microbiol., 5, 801-812.

Śliwa-Dominiak, J., Tokarz-Deptuła, B., Deptuła, W. (2010). F-specific RNA bacteriophages and bacteria of the coli group in water samples from a small urban lake in Szczecin. Woda-Środowisko-Obszary Wiejskie, 10, 189-199 (in Polish).

Śliwa-Dominiak, J., Tokarz-Deptuła, B., Deptuła, W. (2015). Mammalian and bacterial viruses in aquatic enviromentals. Pol. J. Enivronm. Stud., 24, 951-960.

Śliwa-Dominiak, J., Tokarz-Deptuła, B., Deptuła, W. (2014). Occurrence of F-specific RNA coliphages and microbial indicator in municipal lake water. Pol. J. Environm. Stud., 23, 467-473. 
Vergara, G.G.R.V., Goh, S.G., Rezaeinejad, Y., Sobsey, M.D., Gin, K.Y.H. (2015). Evolution of FRNA coliphages as indicators of human enteric viruses in a tropical urban freshwater catchment. Water Res., 79, 39-47.

Zupok, A., Sokołowska, E., Śliwa-Dominiak, J., Tokarz-Deptuła, B. (2010). F-specific bacteriophages RNA in water samples originating from Syrenie Stawy (municipal lake in Szczecin). Mikrobiot 2010 the $2^{\text {nd }}$ workshop on microbiology in health and environmental protection. Łódź, Poland.

Cite as: Pawlikowska-Warych, M., Czupryńska, P., Tokarz-Deptuła, B., Deptuła, W. (2019). Somatic and F-specific bacteriophages in waters of the small, municipal Rusałka Lake in Szczecin. Acta Biologica, 26, 45-55. DOI: 10.18276/ab.2019.26-05. 